\title{
Estimation of financial fraud present in industrial and commercial companies
}

\author{
Julio Maturana Padilla ${ }^{\# 1}$, Raul J. Martelo ${ }^{* 2}$, Natividad Villabona ${ }^{\$ 3}$ \\ \# Independent researcher \\ 1julmp@gmail.com \\ ${ }^{*}$ Faculty of Engineering, INGESINFO research group, University of Cartagena, Colombia. \\ 2 rmartelog1@unicartagena.edu.co \\ ${ }^{\$}$ Faculty of Engineering, INGESINFO research group, University of Cartagena, Colombia. \\ ${ }^{3}$ nvillabonag@unicartagena.edu.co
}

\begin{abstract}
The objective of the present investigation was to analyze the financial fraud in the companies of the industrial and commercial sector in the city of Cartagena, Colombia, for which the most common types of fraud were identified, the necessary conditions for the materialization of the fraud were described and It was determined how is the miso risk management. The type of research was classified as descriptive, field, with no experimental, transactional design. Descriptive statistics was used for data analysis. The results show that financial fraud in the analyzed organizations has a moderate presence of some type of fraud, and of the risk factors, as well as a low presence of risk management mechanisms, which allows inferring that there is a low capacity to face it. It is concluded that financial fraud can occur in the companies studied due to the deficiency of the general conditions of control of the same.
\end{abstract}

Keyword - Risk Factors, Risk Management, Types Of Frauds, Fraud Control, Economic Crimes

\section{INTRODUCTION}

Financial fraud is one of the main concerns worldwide that often produces destructive results and is growing rapidly in many countries. This refers to activities, such as credit card fraud, money laundering, insurance fraud, corporate fraud, among others. It is a criminal act that violates the law, regulations or policy to obtain an unauthorized financial benefit [1]. In the case of corporate fraud, it involves three categories: misappropriation of assets, corruption and fraudulent financial statements [2]. The misappropriation of assets includes the theft or misuse of the assets of an organization [3]. In corruption, employees use their influence in commercial transactions to obtain unauthorized benefits against their duties for employers [4]; and in fraudulent financial statements, it implies that the reported financial statements look better than they really are [5].

In this sense, the Association of Certified Fraud Examiners [6] states that in the period from January 2014 to October 2015, 2,410 reported cases of fraud were analyzed, concluding that because of this, companies lose 5\% of their annual income, which translates into 6.3 trillion US dollars (USD), a significantly high figure considering that $40.7 \%$ of victim organizations do not file complaints about fraud cases, because $75 \%$ of the cases are conceived and executed by people associated with the organization. In the Specific case of Colombia, [7], indicates that about $49 \%$ of the companies subject to a study were victims of financial fraud, estimating that the losses reach 95 million American Dollars.

Due to the above, financial fraud is one of the most evaluated topics worldwide and the literature shows this as in [8], where the mediating roles of the ethical culture and the monitoring control between the link organizational investment and labor fraud. Similarly, [9] analyzes the ways in which fraud was committed and the techniques used to detect them in a local case, where the best tools chosen were the benefits model and the analysis of reasons, which are simple but effective methods for detecting fraud in the financial statements. Also, [10] describes the different forms of fraudulent behavior in the context of financial market activities, the prevalence and consequences of such behavior identified by previous research, and the economic and market structures that facilitate this situation.

Previous studies show the worldwide concern for examining, avoiding and punishing financial fraud. In this sense, the city of Cartagena, because it is an important scenario in the economic development of Colombia, which allows different types of commercial transactions and therefore risks derived from fraudulent actions, it is necessary to know the application of the principles of financial audit, therefore, the objective of this research was to analyze financial fraud and identify the most common types of fraud present in companies in the industrial and commercial sector of this city, so that it serves as a tool or basis for the prevention and detection of it. 


\section{METHODOLOGY}

This research has a positivist approach because it is a quantitative study. The type of research was descriptive, because the purpose is to delimit the facts that make up the research problem, as is the application of the Forensic Audit as a tool for the detection and prevention of financial fraud in companies located in the industrial and commercial sector of the Forest in the city of Cartagena. The above, is based on what was expressed by [11]. In relation to design, it is non-experimental, cross-sectional or cross-field. Not experimental, because it was carried out without deliberately manipulating the variables [12]. Cross-sectional or cross-field, because the information was collected only once and a variable was analyzed, as well as its incidence and interrelation at a certain time and space [13] and field because it was collected directly the information on the subjects investigated in the context where the events occurred [14]. The study population was made up of managers and administrators of Industrial and Commercial Companies in the city of Cartagena, which can be seen in Table 1.

TABLE I. Distribution of population

\begin{tabular}{|c|c|c|c|c|}
\hline No. & Business & Managers & Directors & Total \\
\hline 1 & Trans arrieros s.a.s. & 1 & 2 & 3 \\
\hline 2 & Coveco s.a.s. & 2 & 3 & 5 \\
\hline 3 & Latco Solutions s.a.s. & 1 & 3 & 4 \\
\hline 4 & Servicortes s.a.s. & 1 & 1 & 2 \\
\hline 5 & D \& C Andrade s.a.s & 1 & 1 & 2 \\
\hline 6 & Inversiones MZTt s.a.s. & 2 & 2 & 4 \\
\hline 7 & Francisco J. Escamilla e.u. & 1 & 2 & 3 \\
\hline 8 & Grupo Gees s.a. & 1 & 3 & 4 \\
\hline 9 & Indumagra ltda. & 1 & 1 & 2 \\
\hline 10 & Transporte la cordialidad s.a.s & 1 & 2 & 3 \\
\hline 11 & $\begin{array}{l}\text { Inversiones inmobiliarias Quintero Gomez e } \\
\text { hijos y cia s en }\end{array}$ & 1 & 1 & 2 \\
\hline 12 & Inversiones Tagliaferro Coronel y cia s en c. & 1 & 2 & 3 \\
\hline Total & 14 & 23 & 37 & \\
\hline
\end{tabular}

As for the population sample, the whole population was taken because its size is small, that is, the entire population made up of managers and administrators. The population census is defined as that action where the count of the entire population is taken into account because they are important for the study [15].

\section{A. Research instruments}

As a technique of data collection, observation by the survey was used, because it allows obtaining information by applying a questionnaire or form whose registration is systematic, valid and reliable behavior or behavior [16]. As for the instrument, the questionnaire was used, as it is an instrument that contains details of the population under investigation such as: variables, dimensions and indicators [17]. It was a structured questionnaire with a total of thirty (30), items or reagents, attending to five (05) alternatives of response with the Likert scale with its respective assessment: Always (5), Almost Always (4), Sometimes (3), Hardly ever (2) and Never (1).

Regarding the validity of the same, it was carried out by the expert judgment technique, in which the instrument was submitted to the review of ten (10) experts in the methodology and content area, who after making observations, considered valid and apt to be applied to the population under study. On the other hand, to determine the reliability of the questionnaire, a pilot test was conducted on ten (10) subjects with similar characteristics of the population under study. The responses of the same allowed to determine a reliability coefficient, with the Cronbach's alpha coefficient, which is applied when the questionnaire includes items with multiple response alternatives. Resulting in 0.95 from the Financial Fraud variable, which is above 0.75 considered as reliable, according to [18].

\section{B. Data analysis}

Once the data collection was completed, double entry tables were prepared to process the data obtained from the questionnaire applied to the population under study, made up of managers and administrators. Tabulated and applied techniques of descriptive statistics: percentages of frequency and means. The descriptive statistical treatment was carried out in response to the analysis of the results by indicating, dimension and variables, by virtue of the responses of the respondents. Similarly, to facilitate the understanding of the data, the scale shown in Table 2 was designed. 
TABLE II. Scale for interpretation of results

\begin{tabular}{|c|c|c|c|}
\hline Response options & Ranges & \multicolumn{2}{|c|}{ Categories } \\
\hline Always & $4.01-5$ & High compliance & High presence \\
\hline Almost always & $3.26-4$ & Moderated compliance & Moderated presence \\
\hline Sometimes & $2.49-3.25$ & Under compliance & Low presence \\
\hline Hardly ever & $1.73-2.48$ & Very low compliance & Very low presence \\
\hline Never & $1-1.72$ & Absent compliance & Absent \\
\hline
\end{tabular}

The previous table shows the scale that allows to locate the categories according to the response options to facilitate the interpretation of the results of the research, obtained from the study.

\section{RESULTS}

The results of the investigation are presented below, in which the variable Financial Fraud in the Industrial and Commercial Companies of the Forest sector in the city of Cartagena is examined. To identify the most common types of fraud in these companies, the results of the types of fraud dimension are exposed, with their indicators: Asset misappropriation, fraudulent financial statements and corruption in Table 3, which is done through the data obtained in each indicator and dimension, referring to the absolute and relative frequencies; as well as the average obtained.

TABLE III. Types of Fraud

\begin{tabular}{|c|c|c|c|c|c|c|}
\hline \multirow[t]{2}{*}{ Response category } & \multicolumn{2}{|c|}{$\begin{array}{c}\text { Asset } \\
\text { misappropriation }\end{array}$} & \multicolumn{2}{|c|}{$\begin{array}{c}\text { Fraudulent financial } \\
\text { statements }\end{array}$} & \multicolumn{2}{|c|}{ Corruption } \\
\hline & $\mathrm{rf}$ & af & $\mathrm{rf}$ & af & $\mathrm{rf}$ & af \\
\hline Always & 0.00 & 0 & 3.60 & 4 & 10.81 & 12 \\
\hline Almost always & 39.64 & 44 & 38.74 & 43 & 41.44 & 46 \\
\hline Sometimes & 37.84 & 42 & 38.74 & 43 & 21.62 & 24 \\
\hline Hardly ever & 21.62 & 24 & 18.92 & 21 & 24.32 & 27 \\
\hline Never & 0.90 & 1 & 0.00 & 0 & 1.80 & 2 \\
\hline totals per indicator & 100 & 111 & 100 & 111 & 100 & 111 \\
\hline average of the indicator & \multicolumn{2}{|c|}{3.16} & \multicolumn{2}{|c|}{3.27} & \multicolumn{2}{|c|}{3.35} \\
\hline Category & \multicolumn{2}{|c|}{ Low presence } & \multicolumn{2}{|c|}{ Moderated presence } & \multicolumn{2}{|c|}{ Moderated presence } \\
\hline \multicolumn{7}{|c|}{ average of the dimension: 3.26} \\
\hline \multicolumn{7}{|c|}{ Category: Moderated presence } \\
\hline
\end{tabular}

As can be seen in Table 3, regarding the Asset Misalignment indicator, of the 37 subjects consulted, 39.64\% of the responses indicated that the misuse of assets in companies almost always occurs, 37.84\% sometimes; 21.62\% hardly ever and $0.90 \%$ consider that never, on the other hand, no interviewee considered that this situation always arises. The indicator average reaches 3.16 equivalent to a low presence. On the other hand, for the indicator Fraudulent Financial Statements, the interviewees pointed out that in $38.74 \%$ of the questions considered that fraud is almost always presented in the financial statements, $38.74 \%$ consider that sometimes, an $18.92 \%$ that hardly ever and 3.60\% indicate that always, while the option never, was not selected.

For the last dimension indicator, corruption fraud, $41.44 \%$ of respondents indicated that corruption almost always occurs, $24.32 \%$ consider it almost never, $21.62 \%$ sometimes, $10.81 \%$ indicate, that always, while the option was never selected in 2 of the 111 questions that were asked of the 37 subjects consulted, is $1.80 \%$, to reach an average of 3.35 in the dimension which is equivalent to a moderate presence. The average reached by each of the indicators, evidence as to the identity. The average reached by each of the indicators, evidence regarding the identification of the type of fraud that people consulted perceive the misappropriation of assets with a low presence, while fraudulent financial statements and corruption present a moderate presence, which allows conclude that there is a moderate presence of some type of fraud.

Following with the results, the following are shown those corresponding to the Determinants dimension for the materialization of fraud in Table 4. 
TABLE IV. Determinants for the materialization of fraud

\begin{tabular}{|c|c|c|c|c|c|c|}
\hline \multirow[t]{2}{*}{ Response category } & \multicolumn{2}{|c|}{$\begin{array}{c}\text { Incentives or } \\
\text { pressures }\end{array}$} & \multicolumn{2}{|c|}{ Opportunities } & \multicolumn{2}{|c|}{$\begin{array}{c}\text { Attitudes or } \\
\text { Rationalization }\end{array}$} \\
\hline & $\mathrm{rf}$ & af & $\mathrm{rf}$ & af & $\mathrm{rf}$ & af \\
\hline Always & 3.60 & 4 & 19.82 & 22 & 17.12 & 19 \\
\hline Almost always & 36.04 & 40 & 36.94 & 41 & 36.04 & 40 \\
\hline Sometimes & 31.53 & 35 & 24.32 & 27 & 29.73 & 33 \\
\hline Hardly ever & 24.32 & 27 & 13.51 & 15 & 15.32 & 17 \\
\hline Never & 4.50 & 5 & 5.41 & 6 & 1.80 & 2 \\
\hline Totals & 100 & 111 & 100 & 111 & 100 & 111 \\
\hline average of the indicator & \multicolumn{2}{|c|}{3.10} & \multicolumn{2}{|c|}{3.52} & \multicolumn{2}{|c|}{3.51} \\
\hline Category & \multicolumn{2}{|c|}{ Low presence } & \multicolumn{2}{|c|}{ Moderated presence } & \multicolumn{2}{|c|}{ Moderated presence } \\
\hline average of the dimension & \multicolumn{6}{|c|}{3.38} \\
\hline Category & \multicolumn{6}{|c|}{ Moderated presence } \\
\hline
\end{tabular}

As can be seen in Table 4, regarding the indicator Incentives or Pressures, of the 37 subjects consulted in $36.04 \%$ of the responses indicated that incentives or pressures are almost always present in companies, 31.53\% sometimes; $24.32 \%$ hardly ever and 5.50\% consider never. Likewise, they considered in only 4 opportunities that the condition is always present, which is equivalent to $3.60 \%$. This means that on average the indicator reaches 3.10 points out of 5, placing it in a low presence according to the established scale. On the other hand, for the indicator of fraud by opportunities, respondents indicated that in $36.94 \%$ of their responses they considered that fraud opportunities are almost always present in companies, $24.32 \%$ consider that sometimes, a $19.82 \%$ always $13.51 \%$ hardly ever indicate, while the option never, $5.41 \%$. As a result, the indicator reaches an average of 3.52, which makes it possible to determine a moderate presence of the indicator.

For the last indicator of the dimension, Attitudes or Rationalization for fraud, interviewees pointed out that in $36.04 \%$ of the questions they considered that Attitudes or Rationalization for fraud in companies is almost always presented, $29.73 \%$ consider that sometimes, $15.32 \%$ hardly ever, $17.12 \%$ always indicate, while the option never a $1.80 \%$, to reach an average of 3.35 in the indicator, is a moderate presence. The averages achieved by each indicator allow us to show that in the conditions for the materialization of the fraud, the people consulted perceive that Incentives or pressures have a low presence, while opportunities and attitudes or rationalization have a moderate presence, which allows to conclude that there is a moderate presence of the conditions for the materialization of the fraud.

Continuing with the last dimension Management of fraud risk, its results can be seen in Table 5.

TABLE V. Fraud risk management

\begin{tabular}{|c|c|c|c|c|c|c|c|c|}
\hline \multirow[t]{2}{*}{ Response category } & \multicolumn{2}{|c|}{$\begin{array}{c}\text { Risks } \\
\text { evaluation }\end{array}$} & \multicolumn{2}{|c|}{$\begin{array}{c}\text { Design of } \\
\text { controls }\end{array}$} & \multicolumn{2}{|c|}{$\begin{array}{c}\text { Implementation of } \\
\text { controls }\end{array}$} & \multicolumn{2}{|c|}{ Controls evaluation } \\
\hline & af & $\mathrm{rf}$ & af & $\mathrm{rf}$ & af & rf & af & $\mathrm{rf}$ \\
\hline Always & 8.11 & 9 & 3.60 & 4 & 8.11 & 9 & 0.00 & 0 \\
\hline Almost always & 33.33 & 37 & 26.13 & 29 & 32.43 & 36 & 44.44 & 46 \\
\hline Sometimes & 27.93 & 31 & 28.83 & 32 & 27.93 & 31 & 36.04 & 40 \\
\hline Hardly ever & 30.63 & 34 & 26.13 & 29 & 28.83 & 32 & 22.52 & 25 \\
\hline Never & 0.00 & 0 & 15.32 & 17 & 2.70 & 3 & 0.00 & 0 \\
\hline Totals & 100 & 111 & 100 & 111 & 100 & 111 & 100 & 111 \\
\hline average of the indicator & \multicolumn{2}{|c|}{3.19} & \multicolumn{2}{|c|}{2.77} & \multicolumn{2}{|c|}{3.14} & \multicolumn{2}{|c|}{3.19} \\
\hline Category & \multicolumn{2}{|c|}{ Low presence } & \multicolumn{2}{|c|}{ Low presence } & \multicolumn{2}{|c|}{ Low presence } & \multicolumn{2}{|c|}{ Low presence } \\
\hline average of the dimension & \multicolumn{8}{|c|}{3.07} \\
\hline Category & \multicolumn{8}{|c|}{ Under compliance } \\
\hline
\end{tabular}


The previous table shows the results obtained from the Fraud Risk Management dimension, first, for the Risk Assessment indicator, of the subjects consulted in $33.33 \%$ of the answers indicated that they almost always appear in the companies, $30.63 \%$ hardly ever; $27.93 \%$ sometimes and $8.11 \%$ consider it always. On the other hand, none of the interviewees considered that the indicator never appears. The aforementioned causes an average of the indicator of 3.19, which, according to the established scale determines a low presence. Regarding the indicator Design of controls, respondents indicated in $28.83 \%$ of their responses that anti-fraud controls are sometimes designed, $26.13 \%$ consider that almost always, $26.13 \%$ hardly ever, $15.32 \%$ never indicate, while the option always $3.60 \%$. This results in the indicator reaching an average of 2.77 , which makes it possible to determine that there is a low presence.

On the other hand, for the indicator of Implantation of controls, respondents indicated in $32.43 \%$ of their responses that they almost always observe the implementation of fraud controls in companies, $28.83 \%$ consider that hardly ever, a $27.93 \%$ sometimes, an $8.11 \%$ always indicate, while the option never a $2.70 \%$. Therefore, the indicator reaches an average of 3.14, which makes it possible to determine a low presence of the indicator. Regarding the indicator of evaluation of fraud controls, the interviewees pointed out that in $41.44 \%$ of the questions they considered that almost always some type of evaluation of controls is presented to prevent fraud in companies, $36.04 \%$ they consider that sometimes, $22.52 \%$ hardly ever, while the options never and always were not selected in any opportunity. The average for the indicator was 3.19 of the 5 possible, that is, a low presence.

The average achieved by each of the indicators, evidence in terms of fraud risk management that people consulted perceive that the risk assessment has a low presence, the design of controls, the implementation of controls and the evaluation of controls, they also have a low presence, which in conclusion allows us to conclude that there is a low presence of fraud risk management in Cartagena companies, because the average of the dimension reached a value of 3.07 out of a possible maximum of 5. In this sense, Table 6 presents the summary of the Financial Fraud variable.

TABLE VI. Financial Fraud

\begin{tabular}{|c|c|c|}
\hline Dimension & Average & Category \\
\hline Types of Fraud & 3.26 & Moderated presence \\
\hline Determinants for the materialization of fraud & 3.38 & Moderated presence \\
\hline Fraud risk management & 3.07 & Low presence \\
\hline Variable: Financial Frauds & 3.25 & Moderated Presence \\
\hline
\end{tabular}

Table 6 shows the results by dimension for the Financial Fraud variable, which has a moderated presence, reaching an average of 3.25. Regarding the types of fraud, it is observed that they present a moderated presence, represented by a low presence of the asset misappropriation indicator, a moderated presence of the indicator, fraudulent financial statements and a moderated presence of the Corruption indicator. These results agree with the findings in [19], who points out that all organizations are exposed to some type of risk that is sometimes impossible to control. In the case of the asset misappropriation indicator, the results presented agree with the findings in [20], which indicate that the existence of elements of risk of fraud significantly affects the misappropriation of assets and that if these elements are minimized, the misappropriation of them is reduced.

On the other hand, the results of the Fraudulent Financial Statements indicator are consistent with the findings in [21], where the data obtained show that there are possibilities that the financial statements contain erroneous statements as a result of fraud. In addition, some of the circumstances that indicate the possibility that the financial statements contain a material misstatement resulting from fraud include: Last minute adjustments that significantly affect financial results, followed by transactions that are not recorded in a complete or timely manner or that are incorrectly recorded in terms of their amount. On the other hand, the finding in [22] demonstrates that there is a moderate presence of corruption in commercial companies in industrial companies, also arguing that the level of corruption has a significant impact on the growth of the economy, which implies that the economy cannot grow rapidly without zero tolerance on corruption.

Regarding the results of the Conditions dimension for the materialization of fraud, they place it in the moderated category. The indicator incentives or pressures were categorized as low presence, the indicator opportunities were categorized as having a moderated presence, as well as the indicator attitudes or rationalization. The results of this dimension are corroborated by the findings in [23] where it was found that the risk factors are present in $38.9 \%$ associated with attitude, in $31.8 \%$ corresponding to motivation and $29.3 \%$ associated with conditions. However, the findings in [24] show that the most important indicator is Pressure / Incentive and the least important is Attitude / rationalization. These results present a significant advantage to auditors and managers to improve the efficiency of fraud detection and critical evaluation. 
Finally, in the fraud risk management dimension, a low presence was obtained in the companies located in the industrial and commercial sector of the Forest of the city of Cartagena. Consequently, as stated by Golden, [25], as there is a poor management of fraud risk, the risks are not correctly evaluated in their context, preventing them from having an understanding of the entity's business, the economic environment and the market in which it operates avoiding the presence of other risk factors of fraud can be established. However, for [26] in the assessment of fraud risks, numerous factors are considered as previous instances of a type of fraud, internal control environment, resources available to address fraud, ethical standards, number of transactions involved, complexity, claims and information from external sources, and in the companies studied this information is not presented.

With the results of the indicated dimensions, it can be seen that in the companies located in the industrial and commercial sector of the Forest, the city of Cartagena, there are conditions for the financial fraud to materialize, due to the fact that there is a moderate presence of some kind of fraud, as well as the conditions for the materialization of it. Additionally, it was observed that there is a low presence of fraud risk management mechanisms in the companies studied, which together with the deficiencies of the previous dimensions, exposes companies in the sector to be prone to financial fraud.

\section{CONCLuSION}

Through the investigation, we can see that in the companies located in the industrial and commercial sector of the Forest in the city of Cartagena, there are conditions for financial fraud to materialize, because there is a moderate presence of some type of fraud, as well as the conditions for the materialization of it. In these companies, the three conditions for fraud were observed, which are: incentives or pressures, opportunities and attitudes or rationalization with the following measures: low presence of incentives, median presence for opportunities and attitudes or rationalization. Likewise, it was observed that in the companies under study, there is a low presence of fraud risk management elements, with the adequate design of the controls being the most deficient aspects.

In general, financial fraud can occur in companies located in the industrial and commercial sector of the Forest in the city of Cartagena due to the deficiency of the general conditions of control, which is evidenced by observing a moderated presence of some type of risk, a moderated presence of risk factors and a low presence of fraud control mechanisms.

\section{REFERENCES}

[1] H. Li, \& M. L. Wong, "Financial fraud detection by using Grammar-based multi-objective genetic programming with ensemble learning,” In Evolutionary Computation (CEC) 2015 IEEE Congress, pp. 1113-1120, 2015.

[2] ACFE (Association of Certified Fraud Examiners), "Report to the Nation on Occupational Fraud and Abuse,” ACFE, Austin Texas, 2012.

[3] W. S. Albrecht, C. O. Albrecht, C. C. Albrecht and M. F. Zimbelman, Fraud examination. Cengage Learning, fifth edition, SouthWestern College, 2015.

[4] K. Holtfreter, "Is occupational fraud "typical” white-collar crime? A comparison of individual and organizational characteristics," Journal of Criminal Justice, vol. 33, no. 4, pp. 353-365, 2005.

[5] J. T. Wells, Occupational fraud and abuse. Obsidian Publishing Company, 1997.

[6] ACFE (Association of Certified Fraud Examiners), "Report to the Nation on Occupational Fraud and Abuse,” ACFE, Austin Texas, 2016.

[7] Kroll Advisory Solutions, Informe Global sobre Fraude. 2013.

[8] J. B. Suh, H. S. Shim, and M. Button, "Exploring the impact of organizational investment on occupational fraud: Mediating effects of ethical culture and monitoring control,” International Journal of Law, Crime and Justice, vol. 53, pp. 46-55, 2018.

[9] N. Omar, R. K. Koya, Z. M. Sanusi and N. A. Shafie "Financial statement fraud: A case examination using Beneish Model and ratio analysis,” International Journal of Trade, Economics and Finance, vol. 5, no. 2, p. 184, 2014.

[10] A. Reurink, "Financial fraud: A literature review,” MPIfG Discussion Paper, vol. 16, no.5, 2016.

[11] F.G. Arias, El Proyecto de Investigación. Introducción a la metodología científica, 5th. Edition. Fidias G. Arias Odón, 2012.

[12] S. Palella and F. Martins, Metodología de la investigación cuantitativa, Fedupel editorial, third edition, 2012.

[13] R. Hernández, C. Fernández and P. Baptista, Fundamentos de metodología de la investigación, Mc Graw-Hill. Hoboken, New Jersey, USA, 2010.

[14] F. G. Arias, El Proyecto de Investigación. Introducción a la metodología científica, Fidias G. Arias Odón, fifth edition, 2012.

[15] M. Tamayo, El proceso de la investigación científica, Editorial Limusa, 2004.

[16] R. Hernández, C. Fernández and P. Baptista, Metodología de la investigación, Mc Graw-Hill, 2004.

[17] A. Bavaresco, "Proceso metodológico en la investigación,” Academia Nacional de Ciencias Económicas, 2001.

[18] B. C. Ruíz, “Instrumentos de investigación educativa. Procedimientos para su diseño y validación,” Venezuela: CIDEG, 2009.

[19] J. Zafra, "Metodología para evaluar la efectividad del diseño y operación de los controles en la realización de auditorías basadas en riesgos," Universidad Nacional de Colombia, 2010.

[20] H. H. Mustafa, N. Mohamed and J. Said, "Mitigating asset misappropriation through integrity and fraud risk elements: Evidence emerging economies,” Journal of Financial Crime, vol. 24, no. 2, pp. 242-255, 2017.

[21] S. Sever and A Novak, "Fraud risk assessments: an empirical analysis,” International Journal Vallis Aurea, vol. 2, no. 1, pp. 19-29, 2016.

[22] P. A. Donwa, C. O. Mgbame and O. M. Julius, “Corruption in the oil and gas industry: Implication for economic growth,” European Scientific Journal, vol. 11, no. 22, 2015.

[23] D. Borda, "Importancia relativa de los factores de riesgo de fraude para los auditores internos de Colombia," Universidad Nacional de Colombia, 2015. 
[24] S. Y. Huang, C. C. Lin, A. A. Chiu and D. C. Yen, "Fraud detection using fraud triangle risk factors,” Information Systems Frontiers, vol. 19, no. 6, pp. 1343-1356, 2017.

[25] T. W. Golden, S. L. Skalak and M. M. Clayton, A guide to forensic accounting investigation, John Wiley \& Sons, 2011.

[26] ACFE (Association of Certified Fraud Examiners), “Association of Certified Fraud Examiners Fraud Examiners Manual," Association of Certified Fraud Examiners, Austin, Texas, 2013.

\section{AUTHOR PROFILE}

Julio Maturana Padilla work as full-time professor in the Technological University Foundation Comfenalco (Colombia). Mr. Maturana completed his Master from Rafael Belloso Chacin University (Venezuela). Mr. Maturana completed his undergraduate in Public Accounting at the University Foundation of the Andean Area.

Raúl J. Martelo works as full-time professor at the University of Cartagena (Colombia). Mr. Martelo completed his magister from Industrial University of Santander (Colombia). Mr. Martelo completed his undergraduate in Systems Engineering at the Industrial University of Santander.

Natividad Villabona works as full-time professor in the University of Cartagena (Colombia). Mrs. Villabona completed his Magister from Technological University of Bolivar (Colombia). Mrs. Villabona completed his undergraduate in Industrial Engineering at the Industrial University of Santander. 